\title{
AN INTENSIVELY GRAZED DOWNLAND LUCERNE FARM
}

\author{
R. B. ElliotT \\ Farmer, N gapara
}

\section{Abstract}

This paper describes the development of a dry Downland farm into lucerne, and the increased stocking rates and sheep performance, which gave the opportunity to purchase an additional property. Management experiences with lucerne are discussed, along with future priorities in further development.

\section{INTRODUCTION}

THE writer's original farm is situated at Ngapara, $30 \mathrm{~km}$ inland from Oamaru. It comprises 167 ha of flat to undulating tableland with steep-sided gullies. One hundred hectares, or approximately $60 \%$, are arable.

The average annual rainfall is only $500 \mathrm{~mm}$, and varies from as low as $330 \mathrm{~mm}$ up to $660 \mathrm{~mm}$. Winters are cool and dry, while summers are hot with dry north-westerly winds reducing the effectiveness of higher summer rainfall. Soils commonly dry out in December and remain so until the end of April.

Most of the farm consists of Kauru soils, which have a thin loess cover over reddish-brown sandstone. This tends to dry out quickly in summer. A third of the farm comprises the "more favourable Timaru soil formed from a heavier cover of loess overlying limestone.

\section{THE BEGINNING}

I took possession 11 years ago in 1963. Pastures were extremely poor. Only 700 breeding ewes were carried, yet they went hungry in the early summer. It soon became apparent that, if 1000 ewes were to be carried, something would have to be done about the old pastures.

Lucerne seemed to be the answer, particularly in dry weather. The ewes and lambs were doing extremely well on the only lucerne paddock that existed. My aim became to get as much of the farm into lucerne as possible. 


\section{LUCERNE ESTABLISHMENT}

A start was made by ripping up the older paddocks. Some went into cash crops, while others went into grass plus turnips. A following greenfeed crop of oats proved to be a good smothering crop for weed control, before sowing lucerne in the spring. Normally $9 \mathrm{~kg} / \mathrm{h}$. of lucerne seed with $1 / 2 \mathrm{~kg} / \mathrm{ha}$ of rape are sown. The addition of rape provides valuable lamb fattening or flushing feed.

By November 1963, we were at the beginning of what turned out to be seven to eight years of droughts. It was soon appreciated that, the quicker lucerne seedlings emerged through the ground, the better the stand would be. Suitable moisture was essential to give this quick strike and keep the inoculum alive. The ground had to be in perfect order after a reasonable fallow and have good consolidation.

Lucerne has been sown at different times, but early sowings prove best. Disappointments occurred while trying to get as much lucerne in as quickly as possible. Weeds were a problem when sowing lucerne straight from old grass, or following turnips. Short-cuts just could not be taken.

Cash cropping provided money to continue to put in lucerne. Between 4 and 8 ha of lucerne were sown each year. There. now exists 50 ha subdivided into ten paddocks. This is about half the arable land sown in lucerne:

\section{STOCK PERFORMANCE}

With more lucerne, livestock numbers have increased-with each 4 ha of new lucerne, an extra 50 ewes would be put on. In 10 years, numbers had virtually doubled, with an increase to 1200 breeding ewes and 250 hoggets. This gives an overall farm stocking rate of 8 stock units/ha. Normally there would also- be some 20 ha of barley or wheat and weaner cattle wintered on greenfeed.

Lambing percentages have also increased. During the initial years, they were about $110 \%$, with the lowest being $100 \%$. With a change from Romney to Coopworths, bigger sheep and better feeding, lambing increased to a peak of $155 \%$; this is lambs tailed from ewes to the ram. To give some indication of increased lambings, in 1969 it was 125\%, I970 138\%; $1971142 \%, 1972$ $155 \%$. I attribute $10 \%$ of this to the breed and $90 \%$ to the extra feeding. 
In the year that $155 \%$ occurred, it turned out extremely dry. Less than $120 \mathrm{~mm}$ of rain fell over 5 months. After the first draft, $100 \%$ of lambs were still on hand. The lambs got what little feed remained and the ewes really suffered. Next year lambing fell $30 \%$, indicating what lack of feed was doing.

With these extra lambs, drafting down to $13 \mathrm{~kg}$ in drier seasons allows better feeding of the ewes. This is considered essential to maintain high lambing percentages.

Wool shorn per ewe is 4 to $4.5 \mathrm{~kg}$.

\section{GRAZING MANAGEMENT}

In May grass and lucerne paddocks are shut. The ewes are confined to one or two lucerne paddocks and fed lucerne hay at maintenance rations. Turnips and grass, or greenfeed, take care of feeding after pre-lamb shearing. Lambing starts on September 1 on grass. By mid-September late lambers may go on to lucerne that is 150 to $200 \mathrm{~mm}$ high. They are spread over these paddocks, at 20/ha until tailing. At tailing, the ewes are mobbed up into 400 to 500 ewe mobs, and begin rotating around the available lucerne paddocks, starting with one which has been spelled over winter. Normally 17 to 22 ewes/ha, plus their lambs, can be carried on lucerne from mid-September to drafting.

With paddock sizes of about 4 to 5 ha, shifts occur approximately each 10 days. The aim in deciding when to shift is to look after both the lambs and the lucerne.

Forced grazing of stalks is avoided, and stock are moved when the lucerne starts to grow again from the bottom. In a good season, 4 paddocks in the rotation are enough, but in a dry season 5 or 6 paddocks are required to provide sufficient feed. These extra paddocks are provided by sacrificing further hay cuts.

Weaning takes place at the first drafting in early December, when the lambs average 11 weeks of age. The lambs remain rotationally grazing on spelled lucerne, with ewes following behind to clean up paddocks. They may be fed hay in the summer to maintain condition, while the lucerne is spelled for flushing.

\section{APPRECIATION OF LUCERNE}

Many of the early problems arose with having just one or two paddocks in lucerne. By not rotationally grazing paddocks to the best advantage for lucerne, lucerne growth suffered. It became obvious that lucerne can be overgrazed. Any paddock which had 
been spelled over autumn produced better in the spring. The longer the spell, the better the response.

Spring' spelling definitely helps. A noticeable advantage was seen, at the time of the second cutting, in a paddock which had earlier been taken for hay compared with one which had been grazed, then shut up at the same time.

There were noticeable feed checks in lamb growth rates, going from grass to lucerne and back again, Dry conditions often meant that the small area of lucerne was the only feed for flushing. On and off grazing gave bloat problems with ewes gorging themselves. Since the lucerne area was increased, these problems have largely been overcome.

Years ago it was common belief that one should not flush ewes on lucerne. In one particular year, my poorest ewes, which had been on lucerne, ended up by giving the highest lambing percentage. It appears that, once sheep are used to lucerne, and it is providing them with more feed, they will lamb just as well, if not better, when flushed on lucerne.

Mismotherings have occurred with high lambings. Thirty to forty lambs were noticeably stunted at Christmas time. To overcome this problem with $155 \%$ lambing, the ewes were set-stocked. The lambs did well up till drafting, but by then feed had run out. With no saved lucerne on which to wean lambs, difficulties occurred in getting the rest away. The ewes suffered. Feed was still scarce at flushing, and this was reflected in lowered lambing in the following season. This proved the need to maintain rotational grazing for lucerne growth. Smaller mobs and smaller paddocks may overcome this problem.

\section{PRESENT PROBLEMS}

Lamb deaths occur from red-gut. The lambs are retained on lucerne For better growth. The ability to finish off all lambs and grow out replacement hoggets is worth more than the few losses which occur.

Barley grass is a problem. It spreads quickly into open lucerne and seriously retards growth. Lambs appear the worst offenders in spreading it from the rocks and shelterbelts. Winter mobstocking tends to thin out the barley- grass, but it is not the complete answer. Chemical spraying has become essential. Spraying is considered cheaper, when one can get another 5 or 6 years out of a paddock, rather than having to recultivate the hills with a crawler tractor. Complete spray coverage is a problem. This is why a helicopter was used this year. Also subdividing off rocky 
areas will help this problem. If paddocks are well sited and looked after they will last 15 to 20 years. Otherwise they will run out in 5 to 6 years as barley grass dominates.

\section{LIMITATIONS}

With the aim of maintaining present high lambings and wool weights, it is felt that an upper limit to carrying capacity has almost been reached. The experiences of the drought make me reluctant to stock up further. By sowing lucerne in the remaining dark lying paddocks, extra sheep could be carried in the spring and summer, but they would require more hay to winter them.

Cost of hay today is high and other costs are spiralling. These dark lying paddocks would require increased chemical spraying 'and stand life would be shorter. It has become questionable whether it is worth carrying any extra stock for the return obtained. Greater incentives appear necessary.

With limited opportunity for further development, and with no wish to "sit still" and accept reduced income, an additional property of 320 ha, presently carrying 1200 ewes, was purchased in May this year.

\section{FUTURE PRIORITIES}

It is intended to develop this farm into lucerne in a similar fashion to the original farm. At present the pastures are poor, with more weeds and gorse. It has not been topdressed lately, the soils are poorer, and the contour is again rolling to steep. It will require more lime and superphosphate and will cost more to spray. The average paddock size at present is 18 to 20 ha. These will need to be halved, requiring additional fencing and water reticulation.

To ensure that this development is uninterrupted, and carried out at a rate faster than development out of income would allow, a long-term development loan is desirable. Given this opportunity, development should be- at a faster rate than on the original farm.

$\mathrm{My}$ method of establishing luceme will remain essentially the same, ensuring careful planning to correct soil $\mathrm{pH}$, provide thorough cultivation and consolidation of the soil, and sow when there is moisture. Provided these conditions are met, I have confidence that lucerne will establish.

Stocking rates will increase with more lucerne but these increases will not be too hurried, so as to take care of the young lucerne paddocks. Ir is not expected that the same stocking rates 
that exist on my developed property will be reached. However, doubling the present carrying capacity is expected.

\section{CONCLUSION}

I am sure that 1 could not farm my present stock without lucerne. Development into lucerne, with its associated increased stocking rates and sheep performance, has given me the opportunity to become well established on my first farm. It provided the necessary equity and creditworthiness to purchase this additional land.

If all farmers occupying dryland farms throughout North Otago were to increase their area of lucerne, they could likewise increase stocking rates, be in a better position to overcome droughts, and provide more attractive business enterprises. Everybody benefits from this increased production. It gives long-term benefits both to the farmer and to the North Otago district. 